\title{
Computed tomography examination of the screaming mummy "Unknown-Woman-A"
}

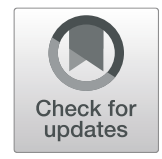

Zahi Hawass $^{1}$ and Sahar N. Saleem ${ }^{2^{*}}$ (D)

\begin{abstract}
Background: The Royal Cache at Deir el Bahari in Luxor, Egypt, contained the mummy of a princess named Meritamun of uncertain identity, who was consequently designated "Unknown-Woman-A." The mummy has a widely opened mouth as if screaming, with the unusual posture of her head tilted to the right and partially flexed legs cross at the ankles. We postulated that computed tomography (CT) would help to provide insights on life and death of "Unknown-Woman-A."

Results: CT findings indicate that "Unknown-Woman-A" died in her fifties (sixth decade of life) and suffered from advanced diffuse atherosclerosis. "Unknown-Woman-A" was well mummified and eviscerated, and her body cavity was filled with resin. The desiccated brain had shifted to the right inside her skull. We presume that "UnknownWoman-A" died of a sudden and massive myocardial infarction. Death spasm induced her unusual posture, and the contracted body was apparently mummified before relaxing her postmortem position.

Conclusions: This CT study has provided useful information about the mummy designated "Unknown-Woman-A" including her mummification style, underlying advanced cardiovascular atherosclerosis disease, and her possible death circumstances.
\end{abstract}

Keywords: Mummy, Egypt, Screaming mummy, Meritamun, Royal Cache

\section{Background}

In 1881, a Royal Cache was discovered at Deir el Bahari in Thebes (modern Luxor) where the priests of Dynasties Twenty-one and Twenty-two reburied and hid mummified royal members of earlier dynasties to protect from tomb thieves [1]. The mummies were transferred to Cairo Egyptian Museum to be examined by Gaston Maspero, then Head of the Egyptian Antiquities Service. There were two mummies from the Royal Cache, a woman and a man who had their mouths widely opened as if they were screaming. The identity of those two mummies could not be settled so Maspero assigned them letters and named them Unknown-Woman-A and Unknown-Man-E [2]. The latter was recently identified as Pentawere, the 20th Dynasty prince who was executed

\footnotetext{
* Correspondence: saharsaleem1@gmail.com

${ }^{2}$ Radiology Department, Kasr Al Ainy Faculty of Medicine, Cairo University, 88 Kasr Al Ainy Street, Cairo, Egypt

Full list of author information is available at the end of the article
}

for conspiring against the life of his father Ramesses III in what is known as the Harem Conspiracy [3].

On June 30th, 1886, Maspero examined "UnknownWoman-A" and recorded on her wraps inscriptions in hieratic writing saying: "Royal daughter, royal sister Meritamun" [2]. However, the mummy was considered unknown as there were several princesses named Meritamun, e.g., the daughter of Seqenenre Taa II $(1558-1553 \mathrm{BC})$ from the end of the 17th Dynasty, as well as the daughter of Ramesses II (1279-1213 BC) from the 19th Dynasty. In 1902, Grafton Elliot Smith, the professor of anatomy, examined "UnknownWoman-A" and described her as a roughly embalmed small frame old woman with tilted head to the right side, widely opened mouth, and slightly flexed legs crossed at the ankles [4]. Maspero and Smith considered the facial expression and the posture of "UnknownWoman-A" as being unusual for the funerary customary and that she might have died in agony $[2,4,5]$. Computed 
tomography $(\mathrm{CT})$ proved to be a powerful non-invasive tool in investigating mummies [6].

We postulated that CT would help to provide insights on life and death of "Unknown-Woman-A" and to shed more light on this part of Egypt's history.

\section{Methods}

The mummy of "Unknown-Woman-A" is housed in the Cairo Egyptian Museum under the code (CG 61052). On the 9th of March 2020, we transferred the mummy to the computed tomography (CT) scanning machine (Somatom Emotion 6; Siemens Medical Solutions, Malvern, Pennsylvania) installed on a truck in the garden of the Cairo Egyptian Museum. We placed foam blocks under the mummy's tilted neck and flexed knees to provide support during the scanning.

We used the following CT scanning parameters of the mummy: KV $=130$ effective MAS range from 23 to 63, pitch range from 0.83 to 1.8, Field-Of-View (FOV) from 320 to 500 , slice thickness from 0.625 to $1.25 \mathrm{~mm}$, and reconstruction from 0.4 to $0.8 \mathrm{~mm}$. FOV selection of a $320 \mathrm{~mm}$ and a detector width of 0.625 provided an isotropic voxel and the highest image resolution. We created axial images. We used a separate workstation (Leonardo Workstation, Siemens Medical Solution) to reconstruct two- and three-dimensional CT images. We used different ranges of window widths for soft tissues and bones. We utilized several reconstruction techniques imaging such as maximum intensity projection (MIP), multiplanar reconstruction (MPR), surface shaded display (SSD), and volume rendering technique (VRT). We analyzed the CT images of the mummy to assess the age at death, gender, pathological findings, and mummification using a methodology published before [1].

We correlated CT findings of mummy of "UnknownWoman-A" with the archaeological data in the literature.

Ethics approval of this study was obtained from The Egyptian Ministry of Antiquities and Tourism Committee.

\section{Results \\ CT findings of the mummy "Unknown-Woman-A" Preservation status}

The mummy is poorly preserved. There is a big defect in the anterior abdominal wall, likely inflicted postmortem by ancient tomb robbers. There is a gaping left inguinal embalming incision. Right upper limb and left forearm are missing. The toes of left foot are disarticulated, while toes of right foot are missing.

\section{Electronic body measurements and stature}

We obtained maximum length measurements of the major long bones. The right femur measures $402 \mathrm{~mm}$, left femur $401 \mathrm{~mm}$, right tibia $338 \mathrm{~mm}$, left tibia 338 $\mathrm{mm}$, right fibula 338, and left fibula $339 \mathrm{~mm}$. Because of the oblique posture of the mummy, it was not possible to obtain vertex to heel measurement. The stature was estimated to be about $151 \mathrm{~cm} \pm 2.5 \mathrm{~cm}$ based from the femur length using regression equation derived for ancient female Egyptians [7].

\section{Age at death}

We estimated that "Unknown-Woman-A" likely died in her fifties based on the following radiological findings: epiphyseal closure of bones, symphysis pubis surface morphology stage 10 using Todd ten-phase pubic system corresponds to +50 years of age $[8,9]$, and dental wear in the maxilla and mandible attrition stage I using Lovejoy system corresponds to $45-55$ years of age [10].

\section{Posture and mummification style}

Physical inspection shows the mummy's head and upper torso are tilted to the right side, the mouth is gaping (Fig. 1), and the legs are partly flexed and crossing at the ankles with the left leg above the right (Fig. 2).

Three-dimensional CT image of the mummy documents the tilted head position (Fig. 3). Two-dimensional CT image shows intactness of the skull base without attempt of brain removal. The desiccated shrunken brain is seen in the CT images shifted to the right side of the

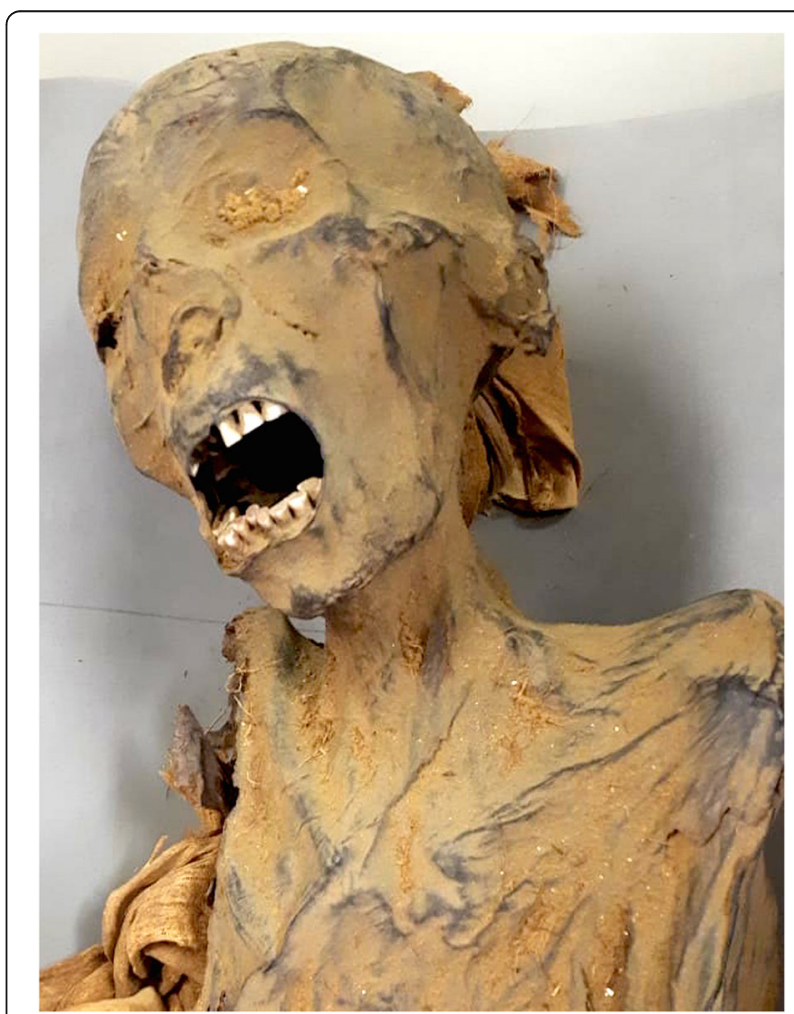

Fig. 1 Picture of the head and upper torso of mummy "UnknownWoman-A." The picture was taken on March 9th, 2020. It shows widely opened mouth and tilted head of the mummy to the right side 


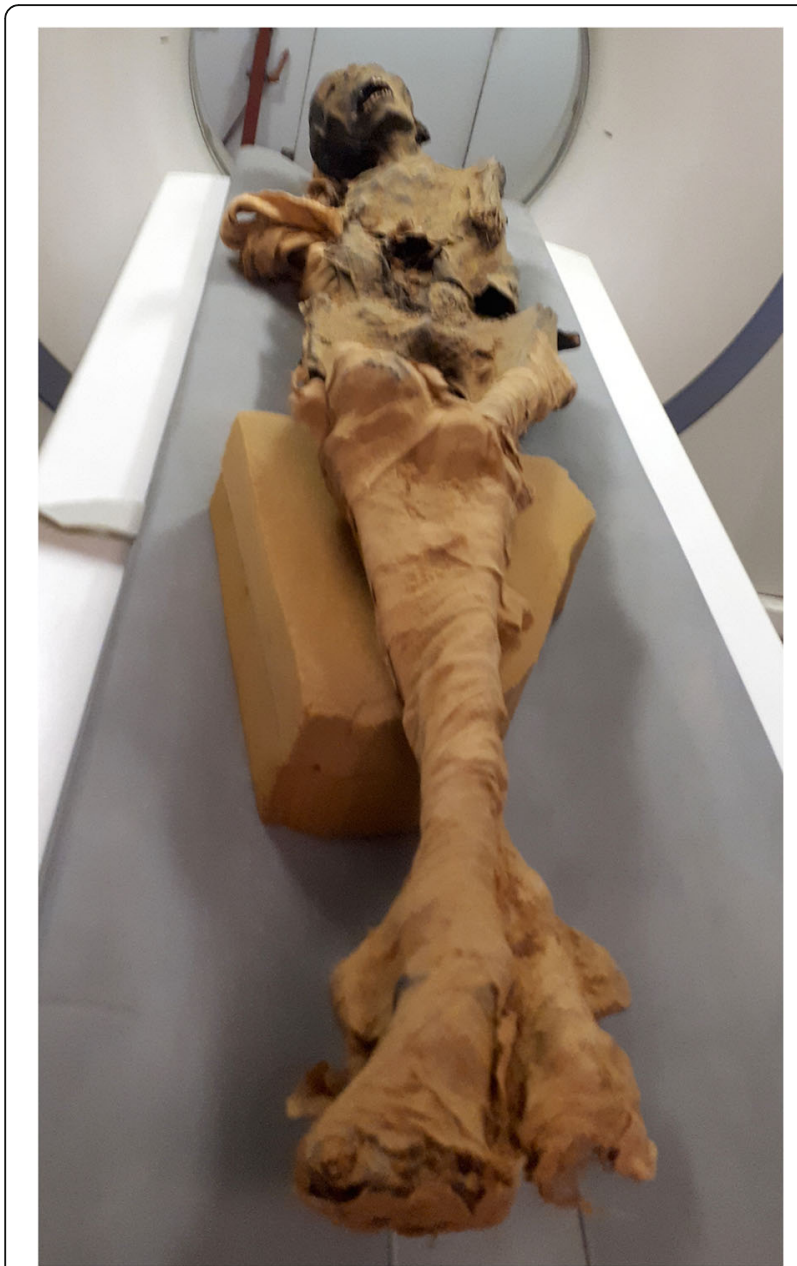

Fig. 2 Picture of the full body of "Unknown-Woman-A." The picture was taken on March 9th, 2020. The mummy has an odd posture with crossed legs at the ankles is evident

cranial cavity. No resin or other embalming materials are seen within the cranial cavity (Fig. 4).

Evidence of evisceration through a left flank incision, the abdominal and pelvic cavities are stuffed with packs of variable CT densities denoting linen $(-100 \mathrm{HU})$ and resin $(70$ to $120 \mathrm{HU})$. The heart, trachea, and large vessels are detected in the thorax (Figs. 5 and 6). No amulets or jewelry is seen within the body cavity or on the mummy's body surface. No subcutaneous packing or artificial eyes are seen.

\section{Pathological findings}

Dental diseases Most of the teeth are carious; the most severely affected are the left first and second lower molars reduced into stumps. Extensive attrition and periodontitis are evident by bone loss between the teeth (Fig. 3). The right upper molar tooth was lost, likely

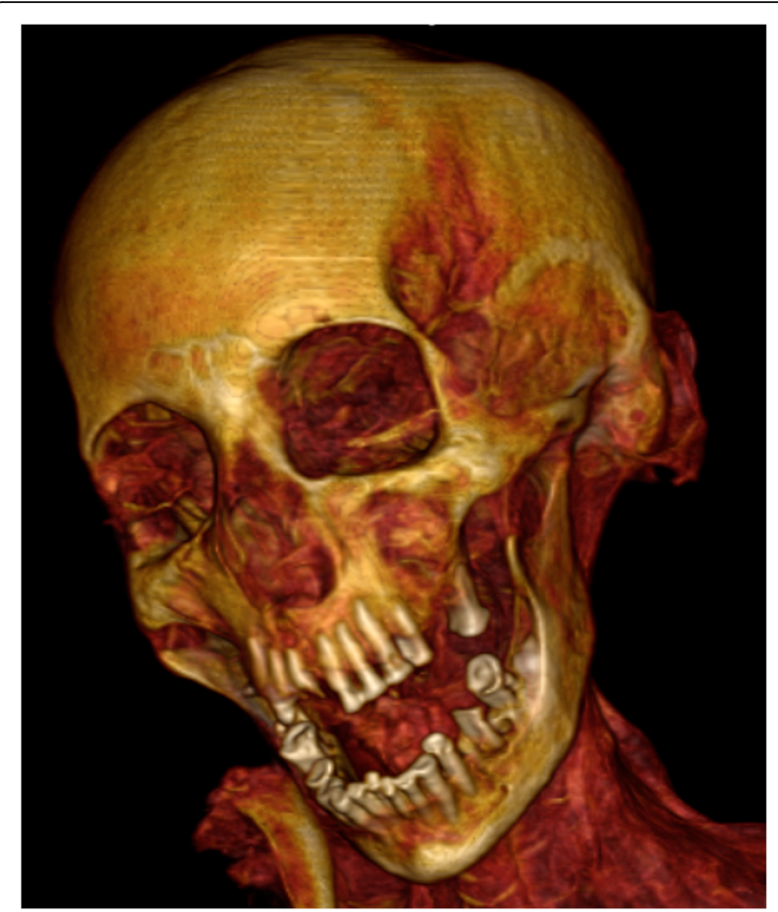

Fig. 3 Three-dimensional CT image of the head of mummy "Unknown-Woman-A." The head is tilted to the right, and the opened mouth shows extensive teeth attrition, periodontitis, and caries

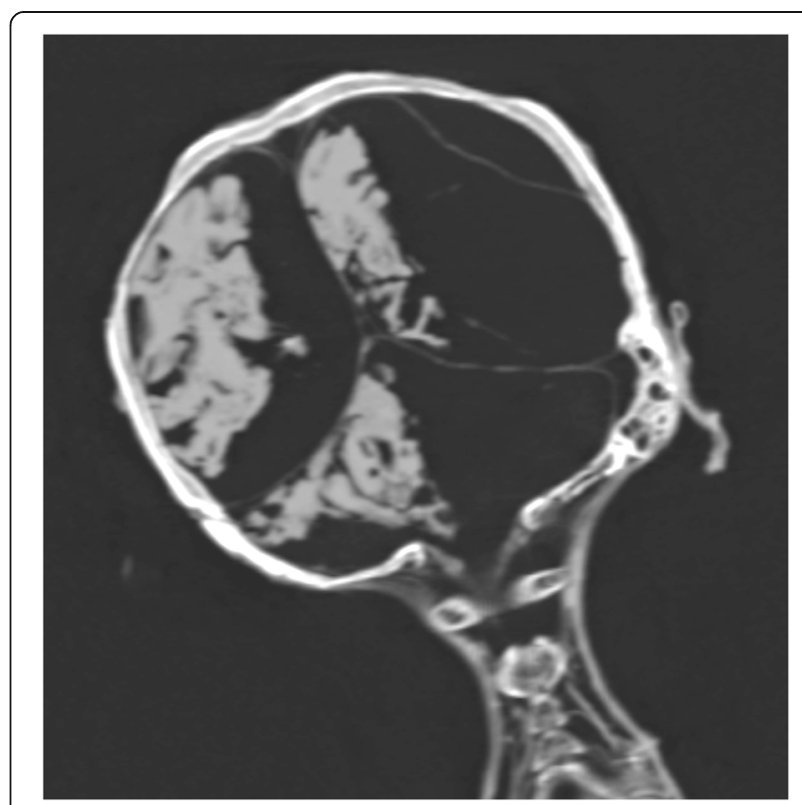

Fig. 4 Coronal $C T$ image of the head and neck of mummy "Unknown-Woman-A." The head is tilted to the right, and the desiccated brain is seen shifted to the right side of the cranial cavity. Teeth attrition could be seen through the gaping mouth 


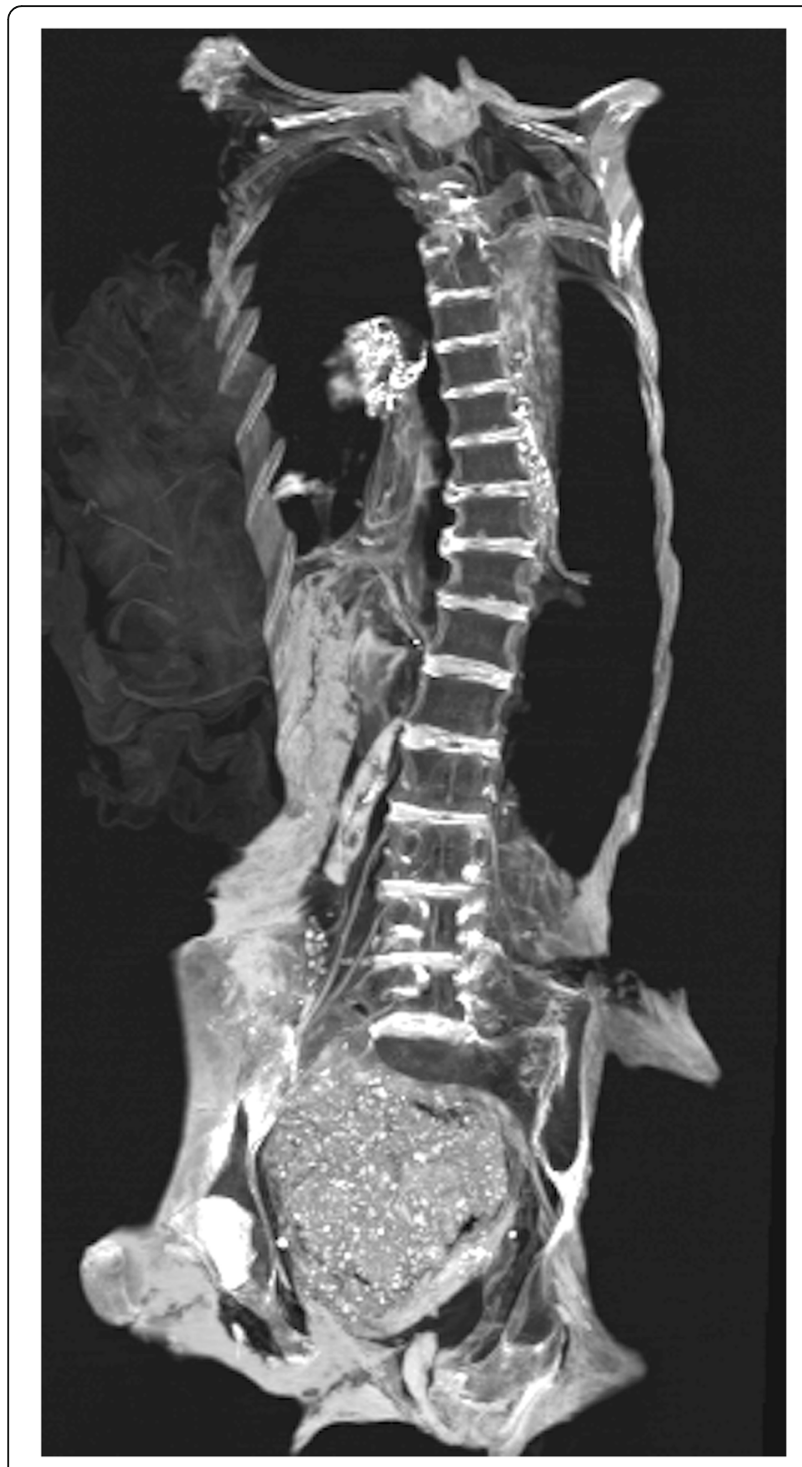

Fig. 5 Coronal CT image of the torso of "Unknown-Woman-A" shows the mummification style. Evidence of evisceration and embalming material placed within the abdomino-pelvic cavity. Note the mild positional scoliosis of the spine

during life, with bone resorption. Several teeth had fallen into the pharynx.

Atherosclerosis Definite atherosclerotic changes are identified as high-density areas of calcification within the walls of identifiable arteries: right and left carotid bulbs, right and left coronary arteries, abdominal aorta, superior mesenteric artery, celiac artery, bilateral iliac, and femoral and peripheral leg arteries (Figs. 7 and 8).

Other findings Mild lateral curvature of the dorsal spine with its convexity to the left (scoliosis) and no structural abnormalities of the spine or anomalous vertebrae could be seen (Fig. 5).

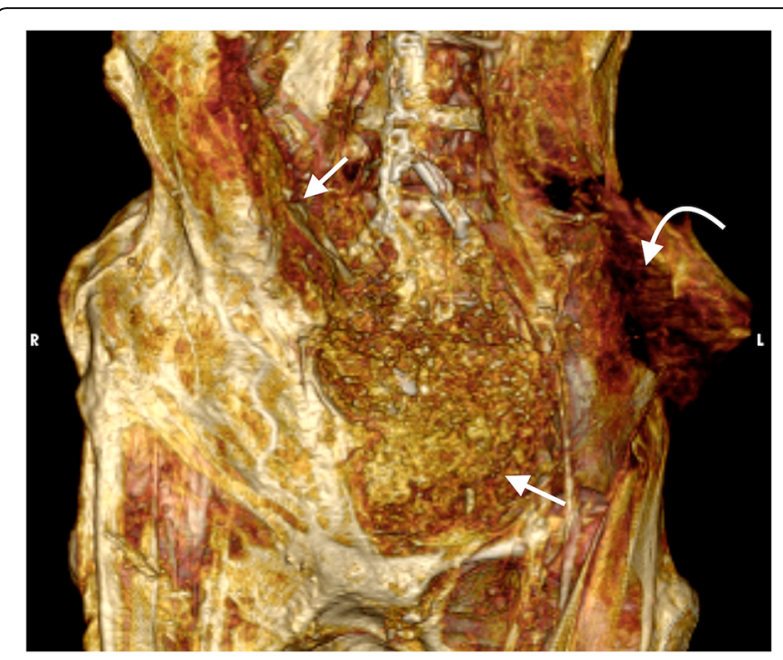

Fig. 6 Three-dimensional reconstructed $C T$ image in frontal projection of the abdomen and pelvis of "Unknown-Woman-A" shows left inguinal incision. The gaping left inguinal evisceration incision (curved arrow) is well shown. The disrupted anterior abdominal wall (likely inflicted by tomb robbers) reveals embalming material packs (straight arrows) within the body cavity

\section{Discussion}

The CT scan of the mummy of "Unknown-Woman-A" shows that she likely died in her fifties. We estimated her age at death from the CT images of her skeleton using the morphology of the pubis symphysis surface, dental attrition, and bony degeneration $[8,10]$. All of the available systems cannot adequately estimate skeletons over age of 50 years [9]. Bony aging depends on several internal and external factors such as nutrition, health, and genetic makeup [11]. When we use bones for aging, we actually estimate the skeletal age rather than the chronological age. This is in concordance with the results of physical examination of the mummy done by Maspero and Smith [2, 4].

When Maspero described "Unknown-Woman-A" as a "distorted mummy," he was referring to her tilted head and upper trunk to the right side, the widely opened mouth, and her partly flexed legs crossed at the ankles [2]. Because of her posture, Smith failed to obtain direct height measurement for "Unknown-Woman-A," and he roughly estimated it $147 \mathrm{~cm}$ [4]. In this study, we applied the accurate CT measurement of the femoral length in a regression equation derived for ancient female Egyptian [7] and calculated $151 \mathrm{~cm}$ as her height. UnknownWoman-A's stature is comparable to the height of most of the royal women of the New Kingdom [1].

The distorted appearance of the mummy of "Unknown-Woman-A" is unusual for the royal funerary customs. Normally, the embalmers made all efforts to ensure a life-like appearance of the deceased; they would place the body stretched out to full length with straight 


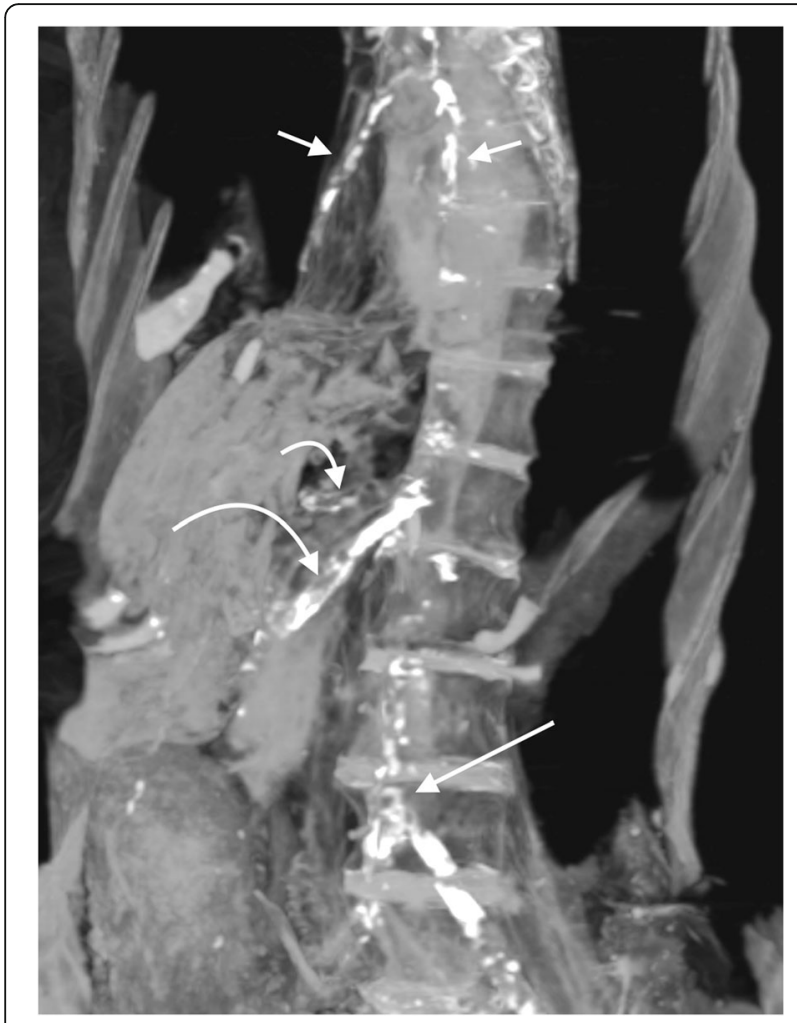

Fig. 7 Computed tomography images of "Unknown-Woman-A" mummy show advanced diffuse atherosclerosis. Coronal thick slab three-dimensional reconstructed computed tomography image of the torso of mummy "Unknown-Woman-A" shows extensive vascular calcifications (atherosclerosis). The high-density calcification lesions involve the right and left coronary arteries (short straight arrows), celiac artery (short curved arrow), superior mesenteric artery (long curved arrow), and aorto-iliac bifurcation (long straight arrow) legs and secured the mouth closed [1]. The articulation of the jaw to the skull (temporo-mandibular joint), supported by muscles and ligaments, controls the opening of the mouth. When these muscles relax during sleeping or when they decompose after death, the mouth opens. To secure the mouth closed, the embalmers usually bandaged the mandible to the skull [5]. The most striking feature of "Unknown-Woman-A" mummy is her widely opened mouth. Ancient mummies with an opened mouth were occasionally found in Egypt [1]. In fact, the Royal Cache of Deir El Bahari, where "UnknownWoman-A" was found, hosted another mummy with a widely opened mouth: "Unknown-Man-E" mummy, sometimes described also as "The Screaming Mummy." Recently, CT and DNA studies identified UnknownMan-E as Pentawere, the disgraced prince who plotted to murder his father King Ramesses III (1185-1153 BC) in what is known as Harem Conspiracy [3]. According to The Judicial Papyrus in Torino Museum, Pentawere was forced to kill himself. This historical fact may explain why Pentawere received minimal mummification unlike other royals. He was found wrapped in a ritually unclean sheepskin instead of the usual linen [3]. Unlike the usual mummification rituals, the CT study of Pentawere's mummy revealed that the embalmers did not remove his body organs (evisceration) or place any embalming material within his body cavity $[1,3]$.

The unusual distorted posture of "Unknown-WomanA" mummy begs the question as to whether the embalmers out of negligence did not bother to secure the mouth closed and squeezed her body (as to fit her inside a smaller coffin). This CT study showed that unlike Pentawere, the body of "Unknown-Woman-A" was in fact well mummified. The embalmers packed her eviscerated body cavity with expensive materials such as resin and scented sawdust, and they used linen to wrap the body

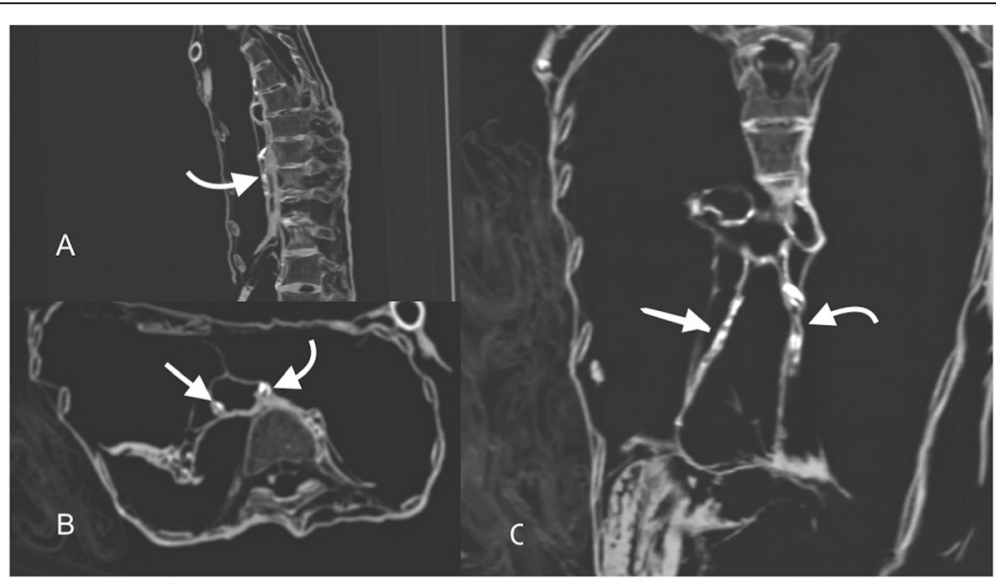

Fig. 8 Coronary atherosclerosis. Compiled CT images of "Unknown-Woman-A" mummy torso in sagittal plane (a), in axial (b), and in coronal plane (c). Presence of high-density calcifications within the course of the right coronary (straight arrow) and left coronary arteries (curved arrows) in multiple planes indicates severe atherosclerosis of the coronary arteries 
[4]. We thus assume that Unknown-Woman-A's death circumstances were likely different than in Pentawere's case.

CT images of the head of mummy "UnknownWoman-A" confirm an intact base and presence of the shrunken brain inside the skull's cavity. Therefore, the embalmers did not attempt to excerebrate (remove the brain) of "Unknown-Woman-A." Similarly, previous Xray and CT studies confirmed that royals dated to late 17th Dynasty to early 18th Dynasty have not been excerebrated, such as Seqenenre Taa II, Thutmose II, and Thutmose III $[6,12]$. The mummy's brain shrinks towards the most dependent position of the skull. We usually see in CT images the shrunken brain occupying the back of the skulls of mummies lying in the usual straight supine position $[1,6]$. In case of mummy of "Unknown-Woman-A" with her tilted head to the right, the desiccated brain is also shifted towards the right side of the cranial cavity (Fig. 3b). We assume in this study that "Unknown-Woman-A" died in this current posture tilted towards the right. The CT scan of the mummy shows mild scoliosis of the dorsal spine. Scoliosis in "Unknown-Woman-A" can possibly be caused by the position of the mummy rather than being structural anomaly, as there are no detectable morphological abnormalities of the spine [1]. "Unknown-Woman-A" must have remained in this postmortem position for some time enough for the desiccating brain to shift towards the most dependent region, namely, the right side.

We also assume that the body posture of "UnknownWoman-A" at death was preserved by a death spasm. Stiffening of muscles and joints following death is termed rigor mortis; it starts few minutes to several hours postmortem, commencing with the face. Another type of spasm is cadaveric spasm and shows the last action prior to death as the contracted muscles become rigid immediately after death without being able to relax [13]. Relaxation of the contracted muscles occurs postmortem when body decomposition starts [13, 14]. We assume that dead body of "Unknown-Woman-A" might not have been discovered until few hours later, enough to develop postmortem spasm. We assume that the embalmers likely mummified the contracted body of "Unknown-Woman-A" before it decomposed or relaxed thus preserving the posture her body took when she died.

CT scans of mummies can sometimes give clues of the cause of death $[1,3]$. CT findings show that "UnknownWoman-A" had severe diffuse atherosclerosis that involved several arteries. Atherosclerosis is a progressive degenerative disease of the arterial wall characterized by plaques formation that can result in lumen narrowing, occlusion, and embolization. The plaques can be detected as high densities in CT images [15].
Previous CT studies showed atherosclerosis in ancient mummies from different parts of the world: ancient Egypt, ancient Peru, Aleutian Islands, and Ancestral Puebloan of Southwest [16]. The estimated age at death of Unknown-Woman-A mummy is comparable to the median age (42.7.5 \pm 10.2 years) of a previously studied group of ancient Egyptian mummies with vascular calcification [17]. The pattern of progression of atherosclerosis across different age groups in ancient Egyptian mummies is similar to modern Egyptians. In both groups, vascular calcification begins at the aorto-iliac artery then involves a decade later to carotid and coronary arteries [17].

"Unknown-Woman-A" had severe atherosclerotic changes that extensively involved the right and left coronary arteries, the right and left carotid, the superior mesenteric artery, the celiac artery, the aorto-iliac, as well as lower limbs arteries. Such extensive coronary artery disease had been reported as a factor in producing mortality. Cardiac diseases, especially coronary artery disease, are the leading cause of sudden death in adults nowadays in several clinical studies [18]. In such condition in modern medicine, clot-busting drugs and coronary angioplasty would have been indicated to prevent or limit damage to the heart muscle [19].

In this study, we assume that "Unknown-Woman-A" had a massive heart infarction resulted in sudden death. An ancient Egyptian medical papyrus, Ebers, describes what seems to be "heart attack" and links it to death: "when you examine a man, who has pains in his stomach, who has pains in his arm and chest on the side of his stomach, wherefore one says: That is the wADsickness (heart attack?). Then you should say to that: Death is nearing him" [20].

Maspero, who was the first to unwrap the mummy in 1886 , Smith who examined the body in 1902, and more recently Dennis Forbes in 1998, all suspected that the facial expression of "Unknown-Woman-A" indicated that she might have died in agony $[2,4,21]$. Human corpuses in ancient Pompeii, Italy, acted as time capsules and retained their postures when they died due to volcanic eruption in $79 \mathrm{AD}[22,23]$. However, other scholars do not believe that a facial expression of a mummy necessarily reflects the emotional status at time of death. According to Aufderheide, several factors might have influenced a mummy's facial appearance, such as the process of putrefaction, rate of desiccation, and the compressing effect of wrappings [24]. We assume that the mouth opening of "UnknownWoman-A" mummy was rather due to the normal jaw drop of the dead, but the contracted muscles must have prevented the embalmers from securing her mouth closed. However, future studies experimenting mummification in ancient Egyptian style may help us to understand possible death spasm and gaping mouths in mummies. 
The identity of mummy "Unknown-Woman-A" has not been settled yet. We know that she was a royal princess named Meritamun per the inscriptions on the mummy wrappings [2]. However, several New Kingdom princesses carried the name Meritamun, e.g., SeqenenreTaa-II's daughter dated to 17th Dynasty and Ramesses II's daughter dated to 19th Dynasty [4]. Mummification technique developed through the ages of ancient Egypt. The embalmers seemed to experiment with ways to accomplish their goal to preserve the body of the deceased for eternity. Thus, special mummification treatment given to the body seemed to vary in style in different time periods of ancient Egypt $[1,6]$. Based on her mummification style, Maspero suggested that "UnknownWoman-A" was not Meritamun daughter of 19th Dynasty Ramesses II but rather a mummy from an earlier time dating to the Middle Kingdom [2]. Elliot Smith dated her to the New Kingdom [1, 4]. At the time of Maspero and Smith, more than a century ago, there were limitations in using mummification to date Egyptian mummies based only on inspection and on limited forensic examinations [5]. Recent CT studies of Egyptian royal mummies helped us outlining some features of mummification in various periods $[1,6,25]$. Similar to "Unknown-Woman-A," some royals dated to late 17th to early 18th Dynasty were not excerebrated, e.g., Seqenenre Taa II, Thutmose II, and Thutmose III $[1,6,12]$. However, excerebration was usually seen in mummified royals of the 19th Dynasty such as Ramesses II $[1,6]$. This CT study thus suggests that "Unknown-Woman-A" could be Meritamun daughter of 17th Dynasty Seqenenre-Taa-II rather than 19th Dynasty Ramesses II. Future DNA study of "Unknown-Woman-A" and other royal mummies may help us to reveal more information concerning her kinship.

\section{Conclusion}

This CT study has provided useful information about the mummy designated "Unknown-Woman-A" including her mummification style, underlying advanced cardiovascular atherosclerosis, and her possible death circumstances.

\section{Abbreviations}

AD: Anno Domini; BC: Before Christ; $C T$ : Computed tomography; DNA: Deoxyribonucleic acid; FOV: Field-Of-View; HU: Hounsfield unit; MIP: Maximum intensity projection; MPR: Multiplanar reconstruction; SSD: Surface shaded display; VRT: Volume rendering technique

\section{Acknowledgements}

We would like to show our gratitude to Dr. Andrew Nelson, Professor of Archaeology/Bioarchaeology-University of Western Ontario, London (ON) Canada, and to Dr. Michael Shkrum, Professor of Forensic PathologyUniversity of Western Ontario, London (ON)-Canada, for sharing their insight and expertise that greatly assisted the research and for revising and providing comments that markedly improved the manuscript.

\section{Authors' contributions}

SNS responsible for the conception and design, acquisition of data, analysis and interpretation of data, wrote the manuscript, generated the figures, and accountable for accuracy and integrity of the work. ZH made substantial contributions in the design, interpretation of the results, drafting the manuscript, and revising it critically for important intellectual content, and agreed to be accountable for the integrity of any part of the work. All authors read and approved the manuscript.

Funding

The research is self-funded by the authors.

\section{Availability of data and materials}

The data collected during the current study are available from the authors on reasonable request and with permission of the Egyptian Ministry of Antiquities and Tourism.

\section{Ethics approval and consent to participate}

This study was approved by The Egyptian Ministry of Antiquities and Tourism Committee. Ethics reference number: not applicable.

\section{Consent for publication}

Not applicable

\section{Competing interests}

The authors declare that they have no competing interests in this study.

\section{Author details}

${ }^{1}$ Cairo, Egypt. ${ }^{2}$ Radiology Department, Kasr Al Ainy Faculty of Medicine, Cairo University, 88 Kasr Al Ainy Street, Cairo, Egypt.

Received: 1 July 2020 Accepted: 15 July 2020

Published online: 27 July 2020

\section{References}

1. Hawass Z, Saleem SN (2016) Scanning the pharaohs: CT imaging of the New Kingdom Royal Mummies. AUC Press, New York

2. Maspero G (1889) Les momies royale de Deir el-Bahari. Ernest Leroux, Paris

3. Hawass Z, Ismail S, Selim A et al (2012) Revisiting the harem conspiracy and death of Ramesses III: anthropological, forensic, radiological, and genetic study. Br Med J 345:e8268. https://doi.org/10.1136/bmj.e8268

4. Smith G (1912) The royal mummies. Catalogue general des antiquités égyptiennes du Musée du Caire Nos 61051-61100 (1912). Bath Press, London

5. Rose M (2009) Screaming mummies! In: Archaeology. Available via https:// archive.archaeology.org/online/features/screaming_mummy/references.html Accessed 27 Apr 2020

6. Saleem SN, Hawass (2013) Variability in brain treatment during mummification of royal Egyptians dated to the 18th-20th dynasties: MDCT findings correlated with the archaeologic literature. Am J Roentgenol 200 (4): W336-W344. doi.https://doi.org/10.2214/AJR.12.9405

7. Raxter MH, Ruff CB, Azab A et al (2008) Stature estimation in ancient Egyptians: a new technique based on anatomical reconstruction of stature. Am J Phys Anthropol 136:147-155. https://doi.org/10.1002/ajpa.20790

8. Todd TW (1920) Age changes in the pubic bones, l: The white male pubis. Am J Phys Anthropol 3:285-334. https://doi.org/10.1002/ajpa.1330030301

9. Meindl RS, Lovejoy CO, Mensforth RP (1983) Skeletal age at death: accuracy of determination and implications for human demography. Hum Biol 55(1): 73-87

10. Lovejoy CO (1985) Dental wear in the Libben population: its functional pattern and role in the determination of adult skeletal age at death. Am J Phys Anthropol 68:47-56. https://doi.org/10.1002/ajpa.1330680105

11. Boskey AL, Coleman R (2010) Aging and bone. J Dent Res 89(12):1333-1348. https://doi.org/10.1177/0022034510377791

12. Harris JE, Wente EF (1980) An x-ray atlas of the royal mummies. University of Chicago Press, Chicago

13. Fierro MF (2013) Cadaveric spasm. Forensic Sci Med Pathol 9(2):253. https://doi.org/10.1007/s12024-013-9414-x

14. Mann RW, Bass WM, Meadows L (1990) Time since death and decomposition of the human body: variables and observations in case and 
experimental field studies. J Forensic Sci 35(1):103-111. https://doi.org/10. 1520/JFS12806J

15. Lusis AJ (2000) Atherosclerosis. Nature 407(6801):233-241. https://doi.org/10. 1038/35025203

16. Thompson RC, Allam AH, Lombardi GP et al (2013) Atherosclerosis across 4000 years of human history: the Horus study of four ancient populations. Lancet 381(9873):1211-1222. https://doi.org/10.1016/S0140-6736(13)60598-X

17. Allam AH, Thompson RC, Wann LS et al (2011) Atherosclerosis in ancient Egyptian mummies: the Horus study. JACC Cardiovasc Imaging 4(4):315327. https://doi.org/10.1016/j.jcmg.2011.02.002

18. de la Grandmaison GL (2006) Is there progress in the autopsy diagnosis of sudden unexpected death in adults? Forensic Sci Int 156(2-3):138-144. https://doi.org/10.1016/j.forsciint.2004.12.024

19. Lusis AJ (2012) Genetics of atherosclerosis. Trends Genet 28(6):267-275. https://doi.org/10.1016/j.tig.2012.03.001

20. Ebers Papyurs (2020). Available via http://www.medizinische-papyri.de/ PapyrusEbers/html/kolumne_xxxvii.html. Accessed 29 Apr 2020

21. Forbes DC (1998) Tombs. Treasures. Mummies: seven great discoveries of Egyptian archaeology. KMT Communications, Sebastopol

22. Knüsel CJ, Janaway RC, King SE (1996) Death, decay, and ritual reconstruction: archeological evidence of cadaveric spasm. Oxf J Archaeol 15(2):121-128. https://doi.org/10.1111/j.1468-0092.1996.tb00079.x

23. Petrone PP (2011) Human corpses as time capsules: new perspectives in the study of past mass disasters. J Anthropol Sci 89:3-6. https://doi.org/10.4436/ jass. 89008

24. Aufderheide A (2003) The scientific study of mummified human remains. Cambridge University Press, Cambridge

25. Wade AD, Nelson AJ (2013) Evisceration and excerebration in the Egyptian mummification tradition. J Archaeol Sci 40:4198-4206. https://doi.org/10. 1016/j.jas.2013.06.017

\section{Publisher's Note}

Springer Nature remains neutral with regard to jurisdictional claims in published maps and institutional affiliations.

\section{Submit your manuscript to a SpringerOpen ${ }^{\circ}$ journal and benefit from:}

- Convenient online submission

- Rigorous peer review

- Open access: articles freely available online

High visibility within the field

- Retaining the copyright to your article

Submit your next manuscript at $\boldsymbol{\nabla}$ springeropen.com 